\title{
Thermal Radiation and Noise Safety Assessment of an Offshore Platform Vent Pipe
}

\author{
Lai Xuejiang ${ }^{1, ~ *, ~ Y a n g ~ Y i ~}{ }^{1}$, Huang $\mathrm{Li}^{2}$, Li Liang ${ }^{3,}$, \\ ${ }^{1}$ School of Mechanical and Power Engineering, Guangdong Ocean University, Zhanjiang, China \\ ${ }^{2}$ Zhanjiang NAWO Survey \& Design Co. Ltd., Zhanjiang, China \\ ${ }^{3}$ School of Physics, Engineering and Computer Science, University of Hertfordshire, Hatfield, UK
}

Email address:

82289412@qq.com (Lai Xuejiang),1.li30@herts.ac.uk(Li Liang)

${ }^{*}$ Corresponding author

\section{To cite this article:}

Lai Xuejiang, Yang Yi, Huang Li, Li Liang. Thermal Radiation and Noise Safety Assessment of an Offshore Platform Vent Pipe. Journal of Energy, Environmental \& Chemical Engineering Vol. 6, No. 3, 2021, pp. 88-93. doi: 10.11648/j.jeece.20210603.16

Received: August 17,2021; Accepted: August 31, 2021; Published: September 8, 2021

\begin{abstract}
The purpose of the offshore platform vent pipe is to release the excess associated gas produced by the oilfield production process in a safe place. Based on the characteristics of the vent pipe of offshore oil platform and the potential hazards of the vent pipe to some working points on the platform caused by sudden emergency discharge, this paper focuses on the analysis of the thermal radiation and noise of each working point on the offshore platform, the thermal radiation and noise of the calculation point were simulated by Flaresim 6.0. The evaluation method is based on the guidelines for pressure relief and decompression systems recommended by the American Petroleum Institute (API RP 521). The simulation results of Flaresim software show that the thermal radiation and noise values of the main working points on the offshore platform meet the requirements of the limits. However, in order to avoid high temperature phenomenon on the surface of the equipment in the working area, low absorptivity coating or protective layer should be used on the surface of the equipment. When vent pipe is empty, the staff should return to the room as far as possible or must wear sound insulation earplug for protection to meet the noise safety assessment. Through the detailed analysis of thermal radiation and noise safety design of offshore platform vent pipe, this study provides an effective reference for similar vent pipe or flare system design projects in the future.
\end{abstract}

Keywords: Offshore Platform Vent Pipe, Thermal Radiation, Noise, Safety Assessment, Flaresim

\section{Introduction}

The vent pipe is to directly and safely discharge the gas which cannot be economically utilized, discharged from normal production and discharged in fault state into the atmosphere. However, direct emission to the atmosphere is conditional, and it is allowed by laws and regulations. If one of the following conditions is met, vent pipe can be selected instead of flare system. The suitable conditions for vent pipe are as follows: the venting only occurs under accident conditions, the venting gas is lighter than air, the concentration of harmful components in the venting gas meets the safety requirements, and the risk of accidental ignition is controllable [1, 2]. Vent pipe emergency assessment method is based on the pressure-relieving and de-pressuring systems guidelines (API RP 521 [3]) recommended United States Petroleum Association. Using
Flaresim Ver. 6.0 calculates the thermal radiation and noise values of vent pipe. As the sudden emergency relief takes place, thermal radiation and noise safety assessment of an offshore platform vent pipe is necessary. The thermal radiation and the noise are released when the vent pipe discharges. According to the platform general layout, a few key points are selected. As long as the point of thermal radiation and noise value is lower than the allowed values, all other positions on the platform of the thermal radiation and noise will also be lower than the allowed value. So personnel on the platform are safety.

\section{Calculating Model}

\subsection{Cold Vent Diffusion Simulation and Analysis}

\subsubsection{Structural Model}

The dimension of the upper deck is $52 \mathrm{~m} \times 33 \mathrm{~m} \times 0.9 \mathrm{~m}$. The 
physical model is shown in Figure 1. The deck of the offshore platform is composed of steel plates, and the support of the platform is also welded by steel. The density of steel is 7.85 $\mathrm{g} / \mathrm{cm}^{3}$.

\subsubsection{Model Meshes Division}

The model calculation space is divided by tetrahedron

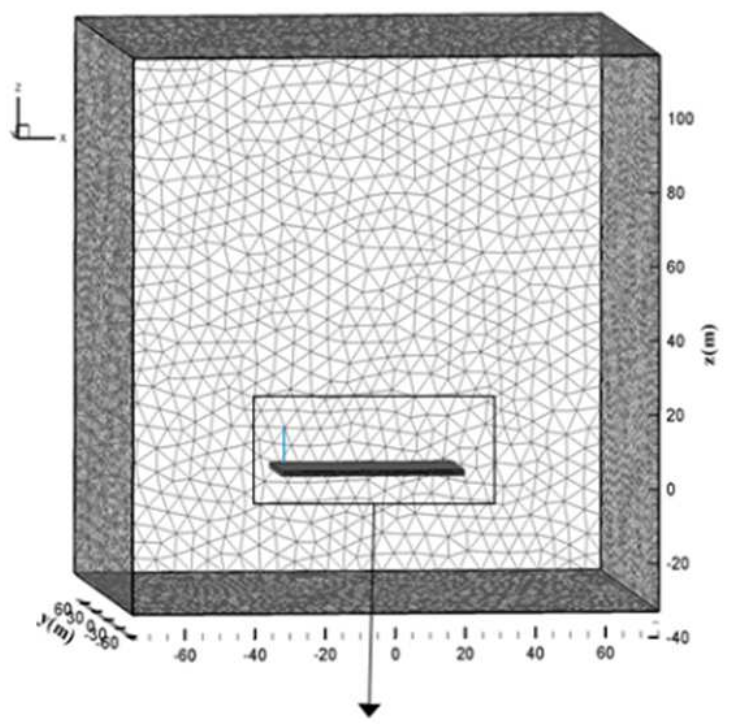

whose length of side is $0.4 \mathrm{~m}$, and the total grids are about 581,953 grid cells. The dimension of the calculation regions is $150 \mathrm{~m} \times 150 \mathrm{~m} \times 150 \mathrm{~m}$. The origin coordinate locates in the center of the upper deck bottom and the coordinate of the vent pipe inlet is $(\mathrm{x}, \mathrm{y}, \mathrm{z})=(-25.3,-16.01,13.05)$.

Figure 1. The model calculation space is divided by tetrahedron.

Calculation Model:

a. The flow model is k-epsilon turbulent model.

b. The diffusion model is species transport model.

c. The effect of gravity is considered.

According to API RP 521, vent pipe calculation includes thermal radiation, surface temperature and noise models. Permissible design levels for personnel are showed in table 1.

Solar thermal radiation intensity is $0.4 \sim 1.04 \mathrm{KW} / \mathrm{m}^{2}$. Thermal radiation intensity is $4.73 \mathrm{KW} / \mathrm{m}^{2}$ as the emergency relief takes place. The solar thermal radiation intensity of south sea is $0.4 \sim 0.8 \mathrm{KW} / \mathrm{m}^{2}$. Choose $0.7 \mathrm{KW} / \mathrm{m}^{2}$ as solar Radiation value.

\subsection{Surface Temperature [4-8]}

The equilibrium surface temperature of metal surfaces

\section{vent}

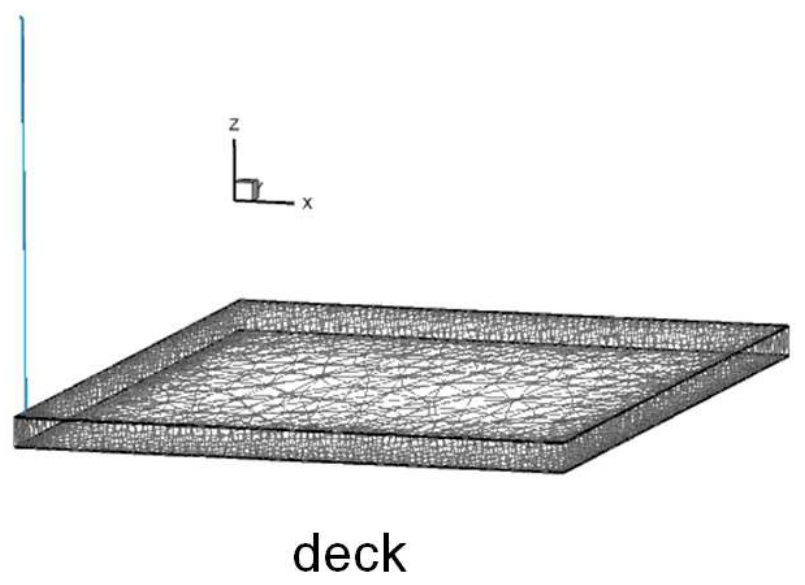

exposed to the thermal radiation is calculated from a heat balance between the thermal radiation from the flame incident at the specified point and the heat losses from the same point. Equation (1) may be used for the surface temperature.

$$
\alpha K=\left(h_{c}+h_{f}\right) \cdot\left(T_{m}-T_{\infty}\right)
$$

where:

$\mathrm{K}$ is thermal radiation at receptor, $\left(\mathrm{W} / \mathrm{m}^{2}\right) ; \alpha$ is metal surface absorbtivity, $\alpha=0.7$;

Table 1. Recommended design thermal radiation for personnel [1].

\begin{tabular}{ll}
\hline $\begin{array}{l}\text { Permissible design } \\
\text { level K }\left(\mathbf{K W} / \mathbf{m}^{2}\right)\end{array}$ & Conditions \\
\hline 1.58 & $\begin{array}{l}\text { Maximum radiant heat intensity at any location where personnel with appropriate clothing*can be continuously exposed } \\
\text { Maximum radiant heat intensity in areas where emergency actions lasting } 2 \text { to } 3 \text { min can be required by personnel without } \\
\text { shielding but with appropriate clothing *. }\end{array}$ \\
4.73 & $\begin{array}{l}\text { Maximum radiant heat intensity in areas where emergency actions lasting up to } 30 \text { s can be required by personnel without } \\
\text { shielding but with appropriate clothing*. } \\
\text { Maximum radiant heat intensity at any location where urgent emergency action the personnel is required reach to. When } \\
\text { personnel enter or work in an area with the potential radiant heat intensity is greater than } 6.31 \mathrm{KW} / \mathrm{m}^{2} \text {, then radiation shielding } \\
\text { and/or special protective apparel (e.g. a fire approach suit) should be considered. } \\
\text { SAFETY PRECAUTIO---It is important to recognize that personnel with appropriate cloth*cannot tolerate thermal radiation at } \\
6.31\end{array}$ \\
& $6.31 \mathrm{KW} / \mathrm{m}^{2}$ for more than a few seconds. \\
\hline
\end{tabular}

* Appropriate cloth consists of hard hat, long-sleeved shirts with cuffs, work gloves, long-legged pants and work shoes. Appropriate cloth can minimizes personnel' s body skin direct exposure to thermal radiation. 
$\mathrm{h}_{\mathrm{c}}$ is the convective heat transfer coefficient which is calculated from a series of empirical correlations that are a function of air velocity.

$$
h_{c}=\left\{\begin{array}{cc}
0.8+0.22 u_{\infty} & 0 \leq u_{\infty} \leq 15 \mathrm{~m} / \mathrm{s} \\
0.56 u_{\infty}^{0.75} & u_{\infty}>15 \mathrm{~m} / \mathrm{s}
\end{array}\right.
$$

This heat balance equation assumes that heat losses by convection and radiation occur only from the surface exposed to the radiation. The overall heat loss from the point is the sum of the radiation from the point and the forced/free convection from the point. The radiative heat transfer coefficient is given by:

$$
h_{f}=\sigma E \frac{\left(T_{m}^{4}-T_{\infty}^{4}\right)}{\left(T_{m}-T_{\infty}\right)}
$$

$E$ is the metal surface emissivity, $E=0.7$;

$\sigma$ is Stephan Boltzman constant, $5.67 \times 10^{-8} \mathrm{~W} / \mathrm{m}^{2} \cdot \mathrm{K}^{4}$;

$u_{\infty}$ is the wind velocity, $\mathrm{m} / \mathrm{s}$;

$T_{\mathrm{m}}$ is the metal surface temperature, $\mathrm{K}$;

$T_{\infty}$ is the atmospheric temperature, $\mathrm{K}$;

\subsection{Vent Pipe Noise [9]}

Vent pipe noise is mainly composed of the combustion noise and the nozzle noise. Although the noise can be represented in average value, it was constituted by different frequencies of noise, each frequency noise contributing to the average value depends on the noise which is caused by the flare combustion noise in a duct or which is caused by the noise of Sonic flare nozzle. The noise spectrum is usually caused by $63 \mathrm{~Hz} \sim 8000 \mathrm{~Hz}$, usually indicated by a sound power level and sound pressure level:

$$
\begin{gathered}
P W L=10 \log \left(\frac{W}{W_{0}}\right) \\
S P L=10 \log \left(\frac{P}{P_{0}}\right)^{2}
\end{gathered}
$$

where:

$P W L$ is sound power level, $\mathrm{dB} ; S P L$ is sound pressure level, $\mathrm{dB} ; W_{0}$ is the reference value, $W_{0}=10^{-12} \mathrm{~W}$;

$P_{0}$ is the reference value, $P_{0}=2 \times 10^{-6} \mathrm{~Pa}$;

When the flare device is positioned in the surrounding empty environment, sound pressure level and sound power levels of noise are as follows:

$$
S P L=P W L-20 \log D-0.49-S P L_{A}
$$

where:

$\mathrm{D}$ is the minimum distance from the flare midpoint to receptor, $\mathrm{m}$;

$S P L_{A}$ is the attenuation of the sound pressure level of noise in the atmosphere, $\mathrm{dB}$. The attenuation is a function of the noise frequency, with higher frequencies being more readily attenuated than lower ones.

$P W L$ is associated with the noise of the vent pipe nozzle.
SPL is associated with the combustion noise.

\section{Calculation Parameter}

The above-mentioned models are calculated by using Flaresim 6.0 software. Calculated parameters include platform environment and vent pipe data, vent gas compositions data and the location of the assessment point information. Platform environment and vent pipe data are showed in table 2. Vent gas compositions data are showed in table 3 . The data in table 2 and table 3 come from the site of the designed platform, the venting amount and the composition of venting gas. Location of the assessment point information is showed in table 4.

Calculation conditions include: SSW wind direction is always towards the check point; Max wind speed is $38 \mathrm{~m} / \mathrm{s}$. The higher the wind speed, the more conducive to the diffusion of emissions, and the smaller the impact on each point on the platform. But when the wind speed is lower, it is not good for gas diffusion, the radiation to each calculation point is higher. Tables 5 and 6 calculated parameters: the ambient temperature is $35.4^{\circ} \mathrm{C}$, Humidity is $97 \%$, Solar Radiation is $0.700 \mathrm{~kW} / \mathrm{m}^{2}$, Back Ground Noise is $50.0 \mathrm{~dB}$.

Table 2. Environment and VENT PIPE data.

\begin{tabular}{ll}
\hline Air average temperature & $\mathbf{2 2 . 9}^{\circ} \mathbf{C}$ \\
\hline Vent gas temperature & $62^{\circ} \mathrm{C}$ \\
Maximal vent gas flow rate & $4.85 \times 10^{4} \mathrm{Sm}^{3} / \mathrm{d}$ \\
Height of vent pipe & $12 \mathrm{~m}$ \\
Diameter of vent pipe & $3^{\prime \prime}(76.2 \mathrm{~mm})$ \\
Humidity (\%) & 81 \\
Low wind speed & $1 \mathrm{~m} / \mathrm{s}$ \\
Maximal wind speed & $38 \mathrm{~m} / \mathrm{s}$ \\
The most dangerous direction of wind & $\mathrm{SSW}$ \\
Maximum ambient temperature & $35.4^{\circ} \mathrm{C}$ \\
\hline
\end{tabular}

Table 3. Vent Gas Compositions Tata.

\begin{tabular}{lll}
\hline Compositions & Chem. formula & Mole fraction \\
\hline Nitrogen & $\mathrm{N}_{2}$ & 0.0145 \\
Carbon-dioxide & $\mathrm{CO}_{2}$ & 0.0388 \\
Water-vapor & $\mathrm{H}_{2} \mathrm{O}$ & 0.0034 \\
Methane & $\mathrm{CH}_{4}$ & 0.8639 \\
Ethane & $\mathrm{C}_{2} \mathrm{H}_{6}$ & 0.0388 \\
Propane & $\mathrm{C}_{3} \mathrm{H}_{8}$ & 0.0295 \\
i-Butane & $\mathrm{C}_{4} \mathrm{H}_{10}$ & 0.0033 \\
n-Butane & $\mathrm{C}_{4} \mathrm{H}_{10}$ & 0.0061 \\
i-Pentane & $\mathrm{C}_{5} \mathrm{H}_{12}$ & 0.001 \\
\hline
\end{tabular}

Table 4. Assessment point information.

\begin{tabular}{lllll}
\hline \multirow{2}{*}{$\begin{array}{l}\text { Assessment } \\
\text { point }\end{array}$} & Description & \multicolumn{3}{l}{ Coordinate $(\mathbf{m})$} \\
\cline { 3 - 5 } & $\mathbf{x}$ & $\mathbf{y}$ & $\mathbf{z}$ \\
\hline 1 & Vent pipe outlet & -25.3 & -16.01 & 13.05 \\
3 & $\mathrm{CO}_{2}$ snuffing system & 8 & -14.94 & 0.9 \\
4 & Helideck & 28 & 0 & 4.2 \\
5 & Living quarter (up) & 15 & -14.94 & -3.3 \\
6 & Material room & 6.37 & -14.94 & 0.9 \\
7 & Central air & 22.8 & -14.94 & 0.9 \\
\hline
\end{tabular}




\section{Safety Assessment Criteria}

\subsection{Radiation Criteria}

Radiation limit shall be as per API RP 521 recommendation. Since emergency relief is typically infrequent and short duration, meanwhile, the $\mathrm{CO}_{2}$ snuffing system can work and the worker can escape within several seconds, so we chose $4.73 \mathrm{KW} / \mathrm{m}^{2}$ as radiation level.

The radiation intensities at the assessment points with wind velocity $\mathrm{v}=1 \mathrm{~m} / \mathrm{s}$ and $\mathrm{v}=38 \mathrm{~m} / \mathrm{s}$ are showed in table 5 and table 6. According to calculating results, the radiation intensities meet the requirements when emergency fire condition occurs.

Table 5. The distribution of radiation intensity in assessment point with $v=1 \mathrm{~m} / \mathrm{s}$, ambient temperature $=35.4^{\circ} \mathrm{C}$. SSW WIND.

\begin{tabular}{|c|c|c|c|c|c|c|c|c|}
\hline Name & $\begin{array}{l}\text { Northing } \\
\text { m }\end{array}$ & $\begin{array}{l}\text { Easting } \\
\text { m }\end{array}$ & $\begin{array}{l}\text { Elevation } \\
\text { m }\end{array}$ & $\begin{array}{l}\text { Radiation } \\
\mathrm{kW} / \mathrm{m}^{2}\end{array}$ & $\begin{array}{l}\text { Noise (A) } \\
\text { dB }\end{array}$ & $\begin{array}{l}\text { Final Temp. }{ }^{\circ} \mathrm{C} \\
\text { Emissivity }=0.9 \\
\text { Absorptivity }=0.1\end{array}$ & $\begin{array}{l}\text { Final Temp. }{ }^{\circ} \mathrm{C} \\
\text { Emissivity }=0.7 \\
\text { Absorptivity }=0.3\end{array}$ & $\begin{array}{l}\text { Final Temp. }{ }^{\circ} \mathrm{C} \\
\text { Emissivity }=0.6 \\
\text { Absorptivity }=0.1\end{array}$ \\
\hline Vent pipe outlet & -16.01 & -25.3 & 13.05 & 12.896 & 131.9 & 56.5 & 1100 & 59.93 \\
\hline Helideck & 0 & 28 & 4.2 & 0.79 & 85.7 & 38.08 & 44.17 & 38.51 \\
\hline Living quarter (up) & -14.94 & 15 & -3.3 & 0.841 & 88 & 38.26 & 44.73 & 38.71 \\
\hline Material room & -14.94 & 6.37 & 0.9 & 0.928 & 90.2 & 38.55 & 45.68 & 39.05 \\
\hline Foam bladder vessel & -14.94 & 26 & 0.9 & 0.8 & 86.3 & 38.12 & 44.28 & 38.55 \\
\hline
\end{tabular}

Receptor Point Summary (Solar Radiation: $0.700 \mathrm{~kW} / \mathrm{m}^{2}$; Back Ground Noise $50.0 \mathrm{~dB}$; tip length=0.1 m).

Table 6. The distribution of radiation intensity in assessment point with $v=38 \mathrm{~m} / \mathrm{s}$, ambient temperature $=35.4^{\circ} \mathrm{C}$. SSW WIND.

\begin{tabular}{|c|c|c|c|c|c|c|c|c|}
\hline Name & $\begin{array}{l}\text { Northing } \\
\text { m }\end{array}$ & $\begin{array}{l}\text { Easting } \\
\text { m }\end{array}$ & $\begin{array}{l}\text { Elevation } \\
\text { m }\end{array}$ & $\begin{array}{l}\text { Radiation } \\
\mathrm{kW} / \mathrm{m}^{2}\end{array}$ & $\begin{array}{l}\text { Noise (A) } \\
\text { dB }\end{array}$ & $\begin{array}{l}\text { Final Temp. }{ }^{\circ} \mathrm{C} \\
\text { Emissivity }=0.9 \\
\text { Absorptivity }=0.1\end{array}$ & $\begin{array}{l}\text { Final Temp. }{ }^{\circ} \mathrm{C} \\
\text { Emissivity }=0.7 \\
\text { Absorptivity }=0.3\end{array}$ & $\begin{array}{l}\text { Final Temp. }{ }^{\circ} \mathrm{C} \\
\text { Emissivity }=0.6 \\
\text { Absorptivity }=0.1\end{array}$ \\
\hline Vent pipe outlet & -16.01 & -25.3 & 13.05 & 12.97 & 131.9 & 38.00 & 43.28 & 38.04 \\
\hline $\mathrm{CO}_{2}$ snuffing system & -14.94 & 8 & 0.9 & 0.9435 & 89.8 & 36.16 & 37.69 & 36.17 \\
\hline Helideck & 0 & 28 & 4.2 & 0.7998 & 85.7 & 35.72 & 36.37 & 35.73 \\
\hline Living quarter (up) & -14.94 & 15 & -3.3 & 0.8598 & 88 & 35.74 & 36.45 & 35.75 \\
\hline Material room & -14.94 & 6.37 & 0.9 & 0.9659 & 90.2 & 35.79 & 36.57 & 35.79 \\
\hline Foam bladder vessel & -14.94 & 26 & 0.9 & 0.8093 & 86.3 & 35.72 & 36.38 & 35.73 \\
\hline
\end{tabular}

Receptor Point Summary (Solar Radiation: $0.700 \mathrm{~kW} / \mathrm{m}^{2}$; Back Ground Noise $50.0 \mathrm{~dB}$; tip length=0.1 m).

By analyzing table 5 and table 6 , the following conclusions can be got.

1) When the vent pipe empties, the radiation at the vent pipe outlet exceeds only the limit value, another points are ok..

2) The change of ambient wind speed has little effect on the radiation of each calculation point, but has a greater impact on the final temperature of the calculation point. When ambient wind speed is $1 \mathrm{~m} / \mathrm{s}$, the air flow is small, the heat from the vent pipe is trapped around the platform, the final temperature of the calculation point is higher than ambient wind speed is $38 \mathrm{~m} / \mathrm{s}$.

3) The decrease of the absorptivity of the equipment at the calculation point can reduce the end temperature of the surface final temperature of the equipment greatly. Try to use coatings or materials with low absorption rate as thermal insulation protective layer.

4) The change of emissivity of the equipment at the calculation point has little effect on the final temperature of the equipment surface.

\subsection{Noise Analysis}

Noise and vibration requirements shall be limited to those noted in this specification, except that where the governing laws of the People's Republic of China are more stringent they shall apply. The follow codes and standard regulations (latest edition if existing) are part of this specification and shall be complied.

\subsubsection{Industry Standards and Codes for Noise}

1) API 615 Sound control of mechanical equipment for refinery service.

2) 29 CFR 1910 Occupational Safety \& Health Standard.

\subsubsection{Industry Standards and Codes for Vibration}

1) API 670 Vibration, axial position and bearing temperature monitoring system.

2) API 678 Accelerometer-based vibration monitoring system.

\subsubsection{Results and Analysis}

Since emergency relief is typically infrequent and short duration, the noise might not be subject to regulation. According to "Safety Rules for Offshore Fixed Platforms", open machinery spaces mean that the equipment is located in open spaces not enclosed around them. The noise value for such spaces shall not exceed $115 \mathrm{~dB}(\mathrm{~A})$. Permissible worker noise level is showed in table 7. By calculating, the noises at the assessment points with wind velocity $\mathrm{v}=1 \mathrm{~m} / \mathrm{s}$ and $\mathrm{v}=38$ $\mathrm{m} / \mathrm{s}$ are showed in table 5 and table 6 . According to the results, wind velocity is not effect on assessment point noise. Vent pipe outlet's noise is $131.9 \mathrm{~dB}(\mathrm{~A})$, exceed $115 \mathrm{~dB}(\mathrm{~A})$. So, the vent pipe outlet should be designed into a noise reducing tip. 
When the vent pipe empties, the noise value of each point is more than $80 \mathrm{~dB}(\mathrm{~A})$, so the influence of background noise value on the combined noise value is very small.
Other assessment point noise is below to remark value. But the outdoor noise exceeds the indoor noise request, so if people want to take rest, he will stay at room.

Table 7. Permissible worker noise level.

\begin{tabular}{ll}
\hline Permissible Exposure & Level dB(A) \\
\hline 12 hours per day & 88 \\
8 hours per day & 90 \\
Less than 8 hours per day & 94 (max.) \\
$* 45$ minutes per day & 100 \\
Control room, office, and lab. & 60 \\
Service area & 65 \\
Public area & 55 \\
Communication room, bedroom, clinic etc. & 45 \\
$*$ Only in special condition, 45 minutes per day criteria shall be applied. & \\
\hline
\end{tabular}

Table 8. The radiation and noise value at the vent pipe outlet with $v=1 \mathrm{~m} / \mathrm{s}$, ambient temperature $=35.4^{\circ} \mathrm{C}$. SSW WIND.

\begin{tabular}{llll}
\hline the tip length $(\mathbf{m})$ & Radiation $\mathbf{k W} / \mathbf{m}^{\mathbf{2}}$ & Noise (A) dB & Final Temp. ${ }^{\circ} \mathbf{C}$ \\
\hline 0.1 & 12.896 & 131.9 & 56.5 \\
1 & 9.423 & 121.3 & 50.99 \\
3 & 5.525 & 111.5 & 44.66 \\
4 & 4.488 & 108.9 & 42.95 \\
6 & 3.212 & 105.4 & 40.83 \\
12 & 1.734 & 99.31 & 38.34 \\
\hline
\end{tabular}

Solar Radiation: $0.700 \mathrm{~kW} / \mathrm{m}^{2}$; Back Ground Noise $50.0 \mathrm{~dB}$ ).

\subsubsection{Increase the Tip Length to Reduce the Noise and Radiation at the Vent Pipe Outlet}

It can be seen from table 5 and table 6 that the noise and radiation at the vent pipe outlet exceed the limits, so the tip length of the vent pipe outlet must be adjusted. See Table 8 for the radiation and noise value at the vent pipe outlet after the tip length adjustment. Although the longer the tip length is, the lower the radiation and noise will be, the more difficult the installation and maintenance will be, and the higher the investment cost will be. Because the frequency of the vent pipe empties the largest amount is not high, the tip length is 12 m. Table 9 shows the radiation and noise values of each calculation point when the tip length is $12 \mathrm{~m}$, and there is no point beyond the limit. However, the noise caused by the venting of the vent pipe is still very high, so it is suggested to install a sound barrier at the vent pipe outlet. Table 10 shows the radiation and noise values of each calculation point with $\mathrm{NNE}$ wind and $\mathrm{v}=2.5 \mathrm{~m} / \mathrm{s}$. Radiation values of each calculation point are lower than each calculation point with SSW wind and $\mathrm{v}=1 \mathrm{~m} / \mathrm{s}$.

Table 9. The distribution of radiation intensity in assessment point with $v=1 \mathrm{~m} / \mathrm{s}$, ambient temperature $=35.4^{\circ} \mathrm{C}$. SSW WIND.

\begin{tabular}{llll}
\hline Name & Radiation $\mathbf{~} W / \mathbf{m}^{2}$ & Noise $(\mathbf{A}) \mathbf{d B}$ & Final Temp. ${ }^{\circ} \mathbf{C}$ Emiss. $=\mathbf{0 . 9}$ Absor. $=\mathbf{0 . 1}$ \\
\hline Vent pipe outlet & 1.734 & 99.31 & 38.34 \\
$\mathrm{CO}_{2}$ snuffing system & 0.8507 & 88.49 & 41.15 \\
Helideck & 0.7784 & 85.20 & 36.86 \\
Living quarter (up) & 0.8075 & 86.89 & 38.42 \\
Material room & 0.8594 & 88.77 & 41.79 \\
Central air conditioning sets & 0.7929 & 86.10 & 41.30 \\
Foam bladder vessel & 0.7843 & 85.63 & 41.24 \\
\hline
\end{tabular}

Solar Radiation: $0.700 \mathrm{~kW} / \mathrm{m}^{2}$; Back Ground Noise $50.0 \mathrm{~dB}$; tip length=12 m).

Table 10. The distribution of radiation intensity in assessment point with $v=2.5 \mathrm{~m} / \mathrm{s}$, ambient temperature $=35.4^{\circ} \mathrm{C}$. nne WIND.

\begin{tabular}{llll}
\hline Name & Radiation $\mathbf{~ k W} / \mathbf{m}^{\mathbf{2}}$ & Noise $(\mathbf{A}) \mathbf{d B}$ & Final Temp. ${ }^{\circ} \mathbf{C}$ Emiss. $=\mathbf{0 . 9}$ Absor. $=\mathbf{0 . 1}$ \\
\hline Vent pipe outlet & 1.783 & 99.31 & 37.54 \\
$\mathrm{CO}_{2}$ snuffing system & 0.8467 & 88.49 & 39.45 \\
Helideck & 0.7748 & 85.20 & 36.70 \\
Living quarter (up) & 0.8050 & 86.89 & 37.46 \\
Material room & 0.8552 & 88.77 & 39.77 \\
Central air conditioning sets & 0.7904 & 86.10 & 39.44 \\
Foam bladder vessel & 0.7821 & 85.63 & 39.40 \\
\hline
\end{tabular}

Solar Radiation: $0.700 \mathrm{~kW} / \mathrm{m}^{2}$; Back Ground Noise $50.0 \mathrm{~dB}$; tip length=12 m). 


\section{Conclusion}

According Flaresim software simulation results, the thermal radiation and noise meet the requirement. In order to avoid high temperature on the surface of the equipment in the working area, the coating or protective layer with low absorptivity should be used on the surface of the equipment. When the vent pipe is empty, the personnel shall return to the room as far as possible or must wear sound insulation earplug for protection. To ensure platform security, $\mathrm{CO}_{2}$ extinguishing system should be installed beside cold vent pipe [10-14].

\section{References}

[1] KANG Lu, CHEN xiaoyu, YANG Zhi, WEIJidnfei. Research on the Thermal Radiation Analysis Method of the Offshore Platform Release Flare [J]. Oil-Gas Field Surface Engineering. 2018, 37 (05): 30-34.

[2] Li Fadong, Liu Di, Zhang Jiedong. Hazard Analysis of Thermal Radiation Elevated Flare Combustion [J]. SAFETY HEALTH \& ENVIRONMENT. 2021, 21 (05): 45-48.

[3] API RP 521. Guide for Pressure-Relieving and De-pressuring Systems [S]. American Petroleum Institute, Fourth Edition, March 1997.

[4] SH 3009-2013. Specifications for Design of Fuel Gas System and Combustible Gas Emission System in Petrochemical Enterprises [S]. State Economic and Trade Commission of People's Republic of China Publish. 2013.

[5] XIA Zhi. Primary Study of Production Relief and Blowdown on the Large-scale Offshore Oil \& Gas Field.[J]. CHINA OFFSHORE PLATFORM. Vol. 27, No. 2 Apr. 2012: 37-40.

[6] XIA Zhi. Flare Simulation Software and Its Application on
Offshore Platform [J]. SHIP BUILDING OF CHINA. Vol. 50, Special, Nov. 2009: 498-502.

[7] J. D. Hajek and E. E. Ludwig, How to Design Safe Flare Stacks, Part1, Petro/Chem. Engineer, 1960, Volume 32, Number 6, pp. C31-C38; Part 2, Petro/Chem. Engineer, 1960, Volume 32, Number 7, pp. C44-C51.

[8] T. A. Brzustowski and E. C. Sommer, Jr., Predicting Radiant Heating from Flares, Proceedings-Division of Refining, 1973, Volume 53, American Petroleum Institute, Washington, D.C., pp. 865-893.

[9] McMurray, R., "Flare Radiation Estimated", Hydrocarbon Processing, Nov. 1982, pp. 175-181.

[10] Narasimhan, N. D., "Predict Flare Noise", Hydrocarbon Processing, April 1986, pp. 133-136.

[11] XIA Zhi, LI Zhi-jun, ZHOU Xiao-hong, WANG Chun-sheng. Verify the Research of FLARE System on Old Platforms of SZ36-1 Old Field [J]. CHINA OFFSHORE PLATFORM. 2009, 24 (6): 46-49.

[12] Pan Bo, Xue Mao-mei, Wang Jun-xia. FLARESIM Software Application in the Design of the Torch [J]. SAFETY HEALTH \& ENVIRONMENT. 2014, 14 (3): 33-35.

[13] SY/T 10033-2000. Recommended Practice for Analysis, Design, Installation and Testing of Basic Surface Safety Systems for Offshore Production Platforms [S]. The Petroleum and Chemical Industry Bureau of People's Republic of China Publish. 2000.

[14] XIA Zhi, ZHOU Xiao-bong, LI Zhi-jun etc. Primary Study of Production Relief and Blowdown on the Large-scale Offshore Oil \& Gas Field [J]. CHINA OFFSHORE PLATFORM. 2012, 27 (2): 37-40.

[15] SY/T 10044-2002. Sizing, Selection and Installation of Pressure-Relieving Devices in Refineries. [S] State Economic and Trade Commission of People's Republic of China Publish. 2002. 